\title{
Active Learning Using Digital Smart Board to Enhance Primary School Students' Learning
}

\author{
https://doi.org/10.3991/ijim.v13i07.10654
}

Soh Hon Mun ${ }^{(凶)}$, Abdul Halim Abdullah, Mahani Mokhtar, Dayana Farzeeha Ali, Nurul Farhana Jumaat, Zakiah Mohamad Ashari, Norazrena Abu Samah

Universiti Teknologi Malaysia, Johor Bahru, Malaysia

munmun1103@live.com.my

Khairul Anuar Abdul Rahman

Universiti Tun Hussein Onn Malaysia, Batu Pahat, Malaysia

\begin{abstract}
Digital smart board is one of interactive technology tools which has been used widely in schools to facilitate teaching and learning. Empirical evidence shows that digital smart board allows students to construct their knowledge while mastering more advanced thinking skills. Thus integration of digital smart board facilitates active learning, which is fundamental to mastery of skills. Active learning using smart board program is a program which integrates smart board in Data Handling so that primary school students can learn Data Handling concept actively and meaningfully. Therefore, this study was conducted to identify the effectiveness of active learning using smart board program to enhance primary school students' learning. Five experts in teaching Mathematics Education and thirty year five students were involved in this study. The students were selected based on purposive sampling. This study used both quantitative and qualitative research approach. A set of interview protocol and a set of questionnaire were used during the data collection phase. Findings from the questionnaire were analysed based on descriptive and inferential statistics by using Winsteps Version 3.72.3. In addition, thematic analysis was used to analyse the qualitative data. Findings from the study indicate that active learning using smart board program has the attributes which can effectively enhance primary school students' learning. It is hoped that the results from this study can contribute towards development of active learning strategies, methods or activities using smart board in order to enhance primary students' learning in school.
\end{abstract}

Keywords-Active learning; digital smart board; primary school students; learning

\section{Introduction}

Learning is seen as using a skill of thinking to arrive at an informed view [5]. It is the process of discovery in which the student is the main agent, not the teacher [1]. Students do not learn much just by sitting in class, listening to teachers, memorizing 
prepackaged assignments, and spitting out answers. Students must talk about what they are learning, write about it, relate it to experiences, and apply it to their daily lives. When students are actively involved in the learning task, they learn more than when they are passive recipients of instruction [9].Students must make what they have learned as part of themselves [6]. Dale's Cone of Learning shows the average retention rate for various methods of learning [10]. It reveals that the least effective method is passive learning such as watching classroom presentations or reading books. In addition, lecture method is also an example of passive learning and it is a relatively poor instructional approach for maintaining students' attention [5]. Lecturing in front of large groups of students who passively absorb ideas that actually demand intense deductive and inductive mental activity coupled with personal experience leave virtually nothing significant or permanent in the student mind [27]. On the other hand, active learning techniques result in up to $90 \%$ retention, and therefore can be considered as effective learning. Dale's Cone of Learning underlines the premise that if teachers show students how to do something, they will probably remember. However if teachers involve them in a meaningful way, they will likely understand the lesson better. In other words, the most durable form of learning is when teachers involve students directly in a meaningful way and preferably through the availability of hands on experience. In addition, students learn best when they use perceptual learning styles which are sensory based since it enables students to interact with resources provided by the teachers.

Active learning is a classroom approach which acknowledges that learners are active in the learning process by understanding and constructing knowledge in response to learning opportunities provided by their teachers [20]. Active learning is based on constructivism theory which states that learning occurs mostly through social interaction with others, such as peers or teachers. Vygotsky defines zone of proximal development (ZPD) as the area where active learning activities should be emphasised, lying between what the learner can achieve with the teacher's professional guidance and what the learner can achieve independently [28]. Understanding information is the key aspect of learning, it is crucial for learners to recognize what they understand and what they do not. By doing so, learners can monitor their mastery of subjects. Meanwhile, teachers actively facilitate students to develop deep level of understanding by providing guidance, scaffolding activities, supporting learners in facing challenges and providing rich feedback using assessment for learning. In addition, learners have more incentive to learn when they have control over not only how they learn but also what they had learnt [16].

Today, many teachers want to adopt active learning as a way to engage students in the learning process. Introduction of technology and computers in academic life has emerged as a necessity [2], [15], [19], [24]. As technology becomes part of social development, new learning technologies should be adopted to update traditional learning approaches [21]. In the last decade, governments around the world have been vigorously promoting the integration of ICT learning as it can lead to significant educational and pedagogical outcomes in schools, and beneficial to learners and teachers [17], [29]. Smart board is popular in the United States educational system. In addition, more than $75 \%$ of classrooms in United Kingdom have adopted the multimedia tech- 
nology [23]. The use of smart board in classrooms provides a lot of benefits to students. It is well-known that students with attention and behavioral difficulties gain benefit from its use. Besides, smart board also facilitated students to visualise mathematics, verify conjectures, involve in active learning strategies, insist positive attitudes, and build confidence in their ability to do mathematics [18].

Several studies review that smart board has great potential to be used as an interactive learning tool with endless motivational application to enhance learning among students. However, smart board alone is not adequate in supporting learning. Thus, it is therefore reasonable to consider the incorporation of smart board with proper learning theoretical framework, particularly active learning. Therefore, findings from this study can be used to support teachers to develop active learning strategies, methods or activities using smart board program in order to promote effective learning.

\subsection{Design and Development of Active Learning Using Smart Board Program}

In order to design interactive learning instruction using smart board program, smart board as a teaching and learning interactive tool needs to be integrated with active learning. A model of active learning [20] is used to design active learning instruction during the teaching and learning process which consists of set induction, step one, step two, step three and closure. Teachers can implement various active learning activities such as dialogue with self, dialogue with others, experience of doing and experience of observing. As a result, learning will be meaningful and effective as every student can participate actively in class. Table 1 shows the mapping of active learning instruction using smart board program.

Table 1. The mapping of active learning instruction using smart board program

\begin{tabular}{|c|c|c|c|}
\hline Steps & $\begin{array}{c}\text { Model of Active } \\
\text { Learning [20] }\end{array}$ & $\begin{array}{c}\text { Smart Board Activi- } \\
\text { ties }\end{array}$ & Examples of Smart Board Activities \\
\hline \multirow[t]{3}{*}{$\begin{array}{l}\text { Set Induction } \\
(\approx 5 \text { minutes })\end{array}$} & \multirow[t]{3}{*}{$\begin{array}{l}\text { Experience of } \\
\text { observing }\end{array}$} & \multirow{3}{*}{$\begin{array}{l}\text { Using visualizer and } \\
\text { smart board software } \\
\text { such as Flipbook, } \\
\text { Sphere 2, as well as } \\
\text { IQ Interactive Educa- } \\
\text { tion Platform to } \\
\text { demonstrate a diver- } \\
\text { gent event or phe- } \\
\text { nomena by showing } \\
\text { pictures or diagrams, } \\
\text { a short practical } \\
\text { activity, present a } \\
\text { problem to be thought } \\
\text { through, a video clip } \\
\text { or film show through } \\
\text { internet and experi- } \\
\text { ment. }\end{array}$} & $\begin{array}{l}\text { Teacher shows two containers of the same size } \\
\text { with different volume of liquid under the visualiz- } \\
\text { er. (Experience of observing) }\end{array}$ \\
\hline & & & 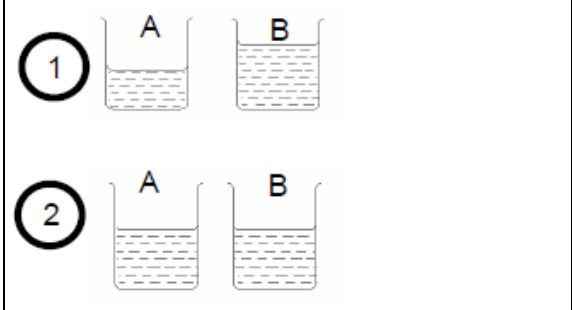 \\
\hline & & & $\begin{array}{l}\text { Teacher asks students to equalise the volume of } \\
\text { liquid in both containers under the visualizer. } \\
\text { Next, teacher adds in more containers of the same } \\
\text { size with different volume of liquid and asks } \\
\text { students to equalise the volume of liquid in the } \\
\text { containers under the visualizer. (Experience of } \\
\text { observing) } \\
\text { Teacher explains to students that they need to find } \\
\text { the average volume of liquid in the containers. }\end{array}$ \\
\hline
\end{tabular}




\begin{tabular}{|c|c|c|c|}
\hline $\begin{array}{l}\text { Step 1 } \\
(\approx 10 \\
\text { minutes) }\end{array}$ & $\begin{array}{l}\text { Dialogue with self } \\
\text { Dialogue with } \\
\text { others } \\
\text { Experience of } \\
\text { observing } \\
\text { Experience of } \\
\text { doing } \\
\\
\end{array}$ & $\begin{array}{l}\text { Using visualizer and } \\
\text { smart board software } \\
\text { such as Flipbook, } \\
\text { Sphere 2, as well as } \\
\text { IQ Interactive Educa- } \\
\text { tion Platform Discus- } \\
\text { sion during experi- } \\
\text { ment, discourses in } \\
\text { small groups, brain- } \\
\text { storming, concept } \\
\text { mapping, practical } \\
\text { work, practical work, } \\
\text { question-answer } \\
\text { session, interview of } \\
\text { events, drawing } \\
\text { pictures to illustrate } \\
\text { science phenomena } \\
\text { and presentation. }\end{array}$ & 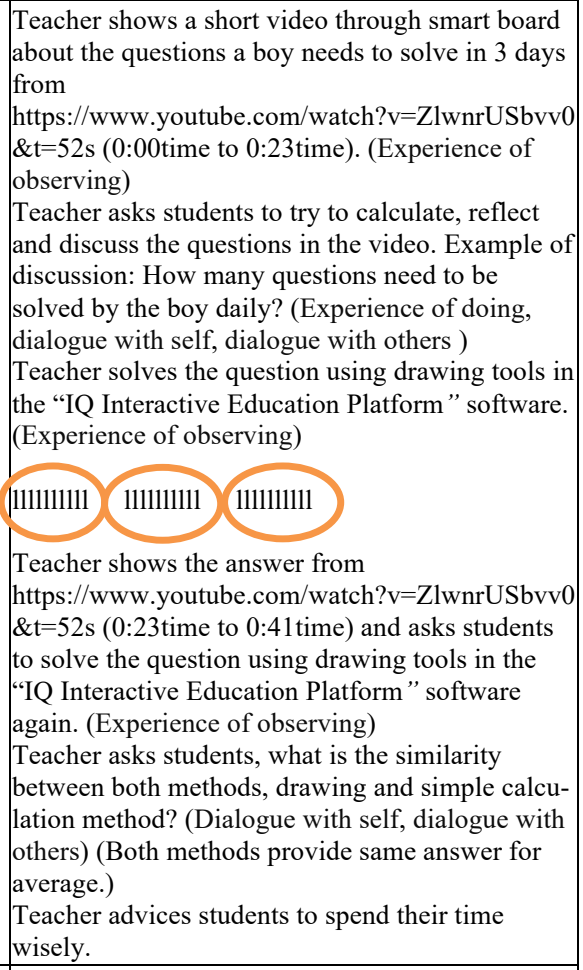 \\
\hline $\mid \begin{array}{l}\text { Step } 2 \\
(\approx 25 \text { minutes })\end{array}$ & $\begin{array}{l}\text { Dialogue with self } \\
\text { Dialogue with } \\
\text { others } \\
\text { Experience of } \\
\text { observing } \\
\text { Experience of } \\
\text { doing } \\
\end{array}$ & $\begin{array}{l}\text { Using visualizer and } \\
\text { smart board software } \\
\text { such as Flipbook, } \\
\text { Sphere 2, and IQ } \\
\text { Interactive Education } \\
\text { Platform during small } \\
\text { group discussion, } \\
\text { project, investiga- } \\
\text { tions, experimenta- } \\
\text { tion, demonstration, } \\
\text { practical work, simu- } \\
\text { lation and presenta- } \\
\text { tion. }\end{array}$ & $\begin{array}{l}\text { Group activity } \\
\text { Teacher asks students to form } 8 \text { groups. } \\
\text { Teacher asks students in the groups to gather all } \\
\text { the money from the group members (RM10, } \\
\text { RM5, RM1, 20sen, 10sen, and 5sen). (Experience } \\
\text { of doing) } \\
\text { Each group is given } 10 \text { minutes to find the aver- } \\
\text { age amount of money belong to each group and } \\
\text { write down the vocabulary related to average on a } \\
\text { piece of paper. (Experience of doing, dialogue } \\
\text { with self, dialogue with others ) } \\
\text { Teacher randomly picks a few groups. Selected } \\
\text { group members need to present their work with } \\
\text { smart board. Using drawing tools in the "IQ } \\
\text { Interactive Education Platform" software. (Expe- } \\
\text { rience of doing, experience of observing) } \\
\text { Dual-user Mode: } \\
\text { Select "Tools, then Dual user" on Menu Bar, } \\
\text { or } \\
\text { Click a. bo Common Tools toolbar. }\end{array}$ \\
\hline
\end{tabular}




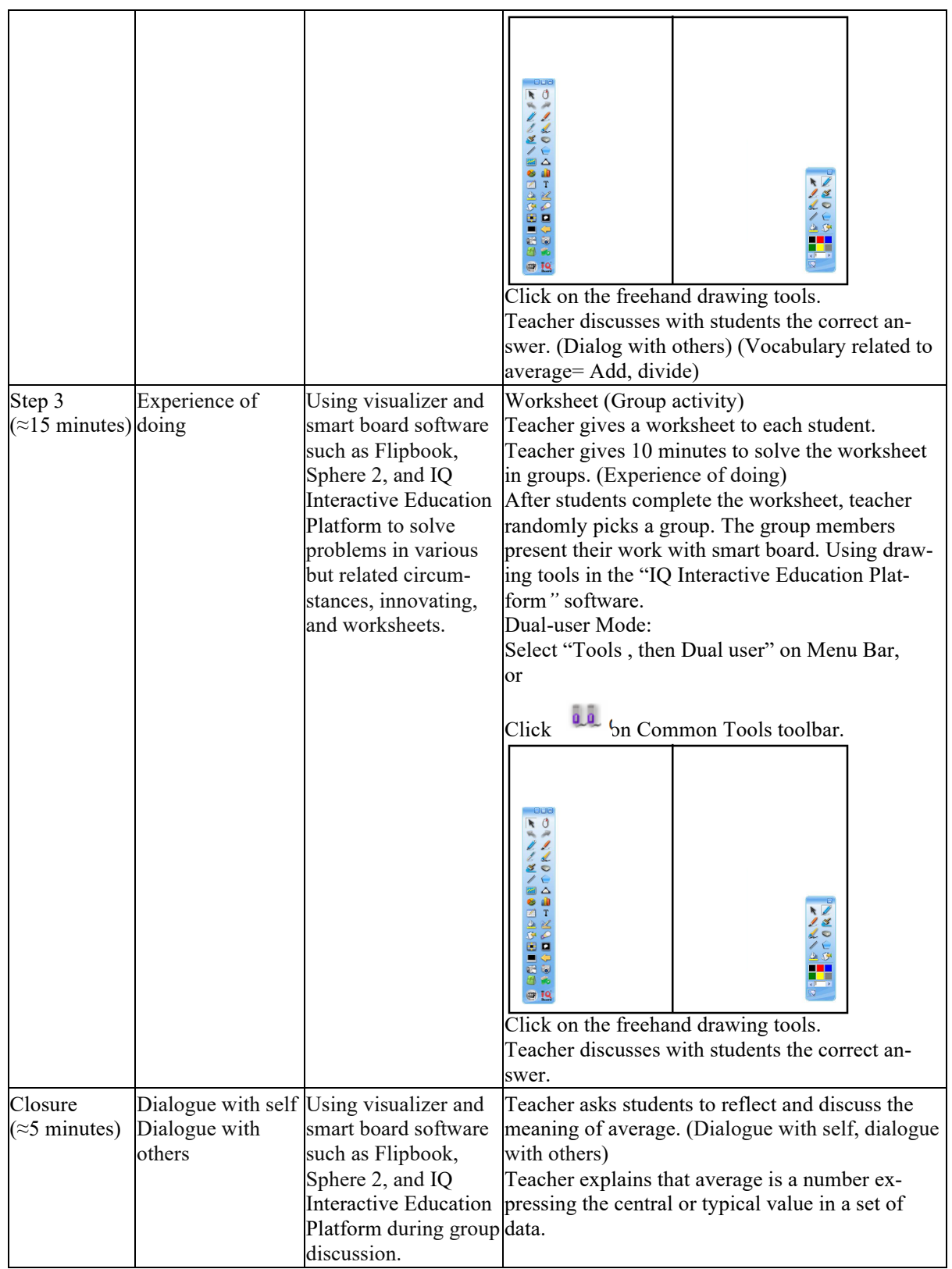

\section{Methodology}

This study used quantitative and qualitative research approaches to identify the effectiveness of active learning using smart board program to enhance learning among primary school students. It was conducted in a Malaysian primary school. The topic of 
Data Handling was selected in this study due to several reasons such as the importance of Data Handling in our daily lives and also career, its instrumental role in other disciplines, as well as the main role of Data Handling in developing critical reasoning [12], [13]. Five teachers who are experts in Mathematics Education and possess more than twenty years of teaching experiences were involved in the process of validating the program. Thirty year five students were involved in this study. The selection of students in this study was based on purposive sampling. They were from different classes with average academic achievement in mathematics. The samples were $46.7 \%$ (14) male students and $53.3 \%$ of them were (16) female students. Twenty percent of them were Malay students (6), 63.3\% were Chinese (19), 6.7\% (2) were Indian and $10 \%$ (3) were other races. This study used a set of interview protocol and a set of questionnaire to collect data. All thirty students were asked to answer interview questions and questionnaire. The questionnaire is about their perceptions towards the learning practices used in Data Handling. It consists of sixteen items and developed based on the theory of social constructivism [28] and active learning [20].The questionnaire uses Likert scale measurement which consists of five points, range from 1 (strongly disagree) to 5 (strongly agree). The findings of the questionnaire were analysed based on descriptive and inferential statistics by using Winsteps Version 3.72.3. Meanwhile, thematic analysis was used to analyse the qualitative data [4].

\section{$3 \quad$ Findings of The Study}

\subsection{Questionnaire analysis}

The purpose of the questionnaire was to study the method used by students to learn HOTS in Data Handling and their perceptions towards the learning practices used in Data Handling. A total of thirty year five students were asked to answer the questionnaire. Table 2 shows mapping of questionnaire items based on theory of social constructivism [28] and active learning [20].

Table 2. Mapping of questionnaire items based on theory of social constructivism and active learning.

\begin{tabular}{|l|c|l|}
\hline \multicolumn{1}{|c|}{ Theory } & Items & \multicolumn{1}{|c|}{$\begin{array}{c}\text { What are the students' perceptions towards the learning } \\
\text { practices used in Data Handling? }\end{array}$} \\
\hline $\begin{array}{l}\text { Vygotsky's social } \\
\text { constructivism [28] }\end{array}$ & B1 & $\begin{array}{l}\text { During the learning processes, I attempt to make connection } \\
\text { between the concepts that I learn. }\end{array}$ \\
\cline { 2 - 3 } $\begin{array}{l}\text { Students are active learners. } \\
\text { They construct meaning } \\
\text { from reality but do not } \\
\text { passively receive what they } \\
\text { are taught in their learning } \\
\text { environment. Learning often } \\
\text { happen and cannot be } \\
\text { separated from social } \\
\text { context. }\end{array}$ & B2 & $\begin{array}{l}\text { When I do not understand any mathematical concept, I find } \\
\text { relevant resources that will help me. }\end{array}$ \\
\cline { 2 - 3 } & B3 & $\begin{array}{l}\text { I can easily illustrate a mathematical concept through } \\
\text { mathematical software applications in smart board. }\end{array}$ \\
\cline { 2 - 3 } & B5 & $\begin{array}{l}\text { I like to solve Data Handling mathematical word problem with } \\
\text { friends in group. }\end{array}$ \\
\cline { 2 - 3 } & B6 & $\begin{array}{l}\text { I am willing to present my thoughts during the classroom } \\
\text { discussion. }\end{array}$ \\
\cline { 2 - 3 } & B7 & I am willing to share my knowledge of mathematical concepts to \\
\hline
\end{tabular}




\begin{tabular}{|l|c|l|}
\hline \multirow{4}{*}{} & & other friends. \\
\cline { 2 - 3 } & B8 & $\begin{array}{l}\text { At the end of learning a topic, I can explain a mathematical } \\
\text { concept to another friend clearly. }\end{array}$ \\
\cline { 2 - 3 } & B9 & $\begin{array}{l}\text { I enjoy learning when a teacher performs Data Handling } \\
\text { mathematical word problem through smart board. }\end{array}$ \\
\cline { 2 - 3 } & B10 & I could apply what I had learnt in class to my daily life. \\
\hline $\begin{array}{l}\text { Active learning [20] } \\
\text { Students are active in the } \\
\text { learning process by } \\
\text { understanding and } \\
\text { constructing knowledge in } \\
\text { response to learning } \\
\text { opportunities provided by } \\
\text { their teacher. All learning } \\
\text { activities consist of dialogue } \\
\text { or experience. }\end{array}$ & B11 & I am willing to attend and make contribution in class. \\
\cline { 2 - 3 } & B12 & I am able to communicate effectively with my classmates. \\
\cline { 2 - 3 } & B13 & $\begin{array}{l}\text { I feel like a part of the class. I always make collaboration with my } \\
\text { classmates. }\end{array}$ \\
\cline { 2 - 3 } & B16 & $\begin{array}{l}\text { I am interested in the learning topics. I could think more critically } \\
\text { about the learning topics. } \\
\text { learning activities. }\end{array}$ \\
\cline { 2 - 3 } & I learn more from doing than from listening. \\
\hline
\end{tabular}

Figure 1 below shows analysis of the perceptions of students towards the learning practices used in Data Handling using Winsteps Version 3.72.3 software. Based on the findings to find out the perceptions of students towards the learning practices used in Data Handling, overall students had high level of perception. The mean score was 3.69 and this showed that students agreed that the use of smart board program while learning Data Handling in class was effective.

\begin{tabular}{|c|c|c|c|c|c|c|c|c|c|c|c|c|c|}
\hline ENTRY & TOTAL & TOTAL & & MODEL & II & FIT & OU & FIT & |PT-ME & SURE & |EXACT & MATCH| & \\
\hline NUMBER & SCORE & COUNT & MEASURE & S.E. & IMNSQ & ZSTD| & MNSQ & ZSTD & |CORR. & EXP. & OBS\% & EXP\%| & ITEM \\
\hline 10 & 53 & 30 & 5.28 & .30 & .68 & -1.5 & .69 & -1.5 & .16 & .24 & 70.0 & 57.5 & B10 \\
\hline 12 & 64 & 30 & 4.29 & .30 & 1.34 & 1.4 & 1.34 & 1.4 & -.15 & .25 & 56.7 & 60.1 & B12 \\
\hline 13 & 68 & 30 & 3.94 & .30 & .86 & -.5 & .86 & -.5 & .17 & .25 & 60.0 & 57.0 & B13 \\
\hline 8 & 75 & 30 & 3.31 & .30 & 1.54 & 2.0 & 1.59 & 2.2 & .51 & .24 & 53.3 & 53.0 & B8 \\
\hline 5 & 111 & 30 & -.14 & .28 & .70 & -1.4 & .70 & -1.4 & .65 & .26 & 53.3 & 51.5 & B5 \\
\hline 6 & 113 & 30 & -.30 & .28 & 1.21 & 1.0 & 1.20 & .9 & .34 & .26 & 43.3 & 52.7 & B6 \\
\hline 4 & 117 & 30 & -.61 & .28 & .71 & -1.4 & .70 & -1.4 & .08 & .26 & 70.0 & 54.1 & B4 \\
\hline 11 & 117 & 30 & -.61 & .28 & .92 & -.3 & .92 & -.3 & .23 & .26 & 56.7 & 54.1 & B11 \\
\hline 14 & 123 & 30 & -1.07 & .28 & 1.40 & 1.7 & 1.47 & 2.0 & .18 & .26 & 36.7 & 55.1 & B14 \\
\hline 15 & 123 & 30 & -1.07 & .28 & 1.24 & 1.1 & 1.24 & 1.1 & -.02 & .26 & 46.7 & $55.1 \mid$ & B15 \\
\hline 1 & 125 & 30 & -1.23 & .28 & .99 & .1 & .98 & .0 & | .37 & .25 & 53.3 & $54.3 \mid$ & B1 \\
\hline 2 & 126 & 30 & -1.31 & .28 & .85 & -.6 & .85 & -.7 & .20 & .25 & 63.3 & 53.7 & B2 \\
\hline 7 & 139 & 30 & -2.55 & .35 & .71 & -1.1 & .70 & -1.1 & .45 & .20 & 66.7 & 65.6 & B7 \\
\hline 9 & 139 & 30 & -2.55 & .35 & .81 & $-.7 \mid$ & .94 & -.1 & .15 & .20 & 66.7 & $65.6 \mid$ & B9 \\
\hline 16 & 139 & 30 & -2.55 & $.35 \mid$ & .77 & $-.9 \mid$ & .78 & -.8 & .31 & .20 & 73.3 & $65.6 \mid$ & B16 \\
\hline 3 & 141 & 30 & -2.81 & .38 & .82 & $-.6 \mid$ & .80 & -.6 & .29 & .19 & 76.7 & 71.0 & B3 \\
\hline MEAI & 110.8 & 30.0 & .00 & .30 & .97 & -.1 & .99 & -.1 & & & 59.2 & 57.9 & \\
\hline S.D. & 28.2 & .0 & 2.58 & .03 & .27 & 1.1 & .28 & 1.2 & & & 10.9 & 5.7 & \\
\hline
\end{tabular}

Fig. 1. Analysis of the perceptions of students towards the learning practices used in Data Handling

Item B3 which states "I can more easily illustrate a mathematical concept through mathematical software applications in smart board" showed the highest mean score of 4.7. This result indicated that students strongly agreed on the effectiveness of smart board usage in class. In addition, item B9 which states "I enjoy learning when a teacher performs Data Handling mathematical word problem through smart board" and item B16, "I learn more from doing than from listening" also recorded high mean 
score of 4.63. Thus, most of the students agreed that they enjoyed learning using smart board and would learn better if they were learning actively in class. However, item B10 "I could apply what I had learnt in class to my daily life" showed the lowest mean score of 1.8. This indicated that the students could not apply their knowledge and skills in their daily lives if they learn passively in class. Moreover, most students in the class faced difficulty to communicate effectively and work together with friends to accomplish mathematical tasks as item B12 "I am able to communicate effectively with my classmates" and item B13 "I feel like a part of the class. I always made collaboration with my classmates" showed low mean score of 2.13 and 2.27 respectively.

\subsection{Interview analysis}

An in-depth one-to-one interview was conducted by the researcher with students who used active learning using smart board program. The interview started with short briefing about the interview protocol before the actual interview sessions. Findings from the students' interview data are as follow:

\section{Feedback from the students who used active learning smart board program}

- The students suggested that there should be user manual provided for them when they were asked to use the program.

- The students highlighted that the program made Data Handling lessons to become fun and interesting.

- The interactive white board really helped the students in learning Data Handling. They stated that the whiteboard was not only a giant touch screen but also a tool to build virtual reality world.

- Students needed to be familiar with the use of smart board before conducting the active learning using smart board program.

- Active learning using smart board program provided the students with strategies or alternative approaches to calculate and this helped to boost their general mathematics understanding.

- Active learning using smart board program has built-intelligence which allowed the s students to visualise all data in table, charts and graphs clearly.

- Active learning using smart board program showed various Data Handling questions and able to define relationships between each data clearly.

- Active learning using smart board program helped the students in making better and faster decisions as it provided a systematic way to create, retrieve, update and manage data.

- Active learning using smart board program showed clear steps to create various graph.

Most of the students who used active learning using smart board program shared similar interest on the features in the program. Active learning using smart board program made learning Data handling to be fun and effective. In addition, the program has the attributes to encourage active, meaningful and thoughtful learning among students. As a result, knowledge and skills learnt in class could be successfully 
retained in memory. Another advantage of active learning using smart board program was that students were able to turn data in understandable information, involved themselves in various interactive activities which train and help them to understand better the concept of Data Handling. Active learning using smart board program encouraged the students to be active learners in the learning process as well as encouraged students to reflect their learning.

\subsection{Excerpts from the experts}

Five teacher experts in Mathematics Education and possess more than twenty years of teaching experiences were asked to validate the active learning using smart board program. Table 3 shows the feedback from the experts about the lesson plans of active learning using smart board program.

Table 3. Feedback from experts about the lesson plans of active learning using smart board program

\begin{tabular}{|c|l|l|}
\hline No. & \multicolumn{1}{|c|}{ Correction required } & \multicolumn{1}{|c|}{ Correction made } \\
\hline 1 & No time located for each lesson plan. & Time located for each lesson plan was written. \\
\hline 2 & $\begin{array}{l}\text { Answer sheets for student's worksheets } \\
\text { were not prepared. }\end{array}$ & $\begin{array}{l}\text { Answer sheets for the students worksheets was } \\
\text { prepared. }\end{array}$ \\
\hline 3 & $\begin{array}{l}\text { Meaning of each symbol of active learning } \\
\text { activities was not stated. }\end{array}$ & Note for active learning activities was written. \\
\hline 4 & $\begin{array}{l}\text { Active learning activities should be written } \\
\text { clearly in the lesson plan. }\end{array}$ & $\begin{array}{l}\text { A column for active learning was written in the lesson } \\
\text { plan. }\end{array}$ \\
\hline 5 & $\begin{array}{l}\text { Active learning activities embedded in the } \\
\text { lesson plan was not stated clearly. }\end{array}$ & $\begin{array}{l}\text { Sample of active learning activities was written clearly } \\
\text { in the teaching and learning activities. }\end{array}$ \\
\hline 6 & $\begin{array}{l}\text { Higher order thinking skills should not be } \\
\text { written in the remark column. }\end{array}$ & $\begin{array}{l}\text { Higher order thinking skills written in the remark } \\
\text { column was removed. }\end{array}$ \\
\hline 7 & $\begin{array}{l}\text { Grammar mistake was found in the lesson } \\
\text { plan. }\end{array}$ & $\begin{array}{l}\text { Grammar mistake found in the lesson plan was } \\
\text { corrected. }\end{array}$ \\
\hline 8 & $\begin{array}{l}\text { Questions in the student's worksheets } \\
\text { should generate students thinking skills. }\end{array}$ & $\begin{array}{l}\text { For the student's worksheets, fill in the blanks } \\
\text { questions were replaced with open-ended questions. }\end{array}$ \\
\hline 9 & $\begin{array}{l}\text { Guidelines should be prepared for the active } \\
\text { learning using smart board program. }\end{array}$ & $\begin{array}{l}\text { Active learning using smart board program handbook } \\
\text { was prepared for the program. }\end{array}$ \\
\hline 10 & $\begin{array}{l}\text { The year of primary school students was not } \\
\text { stated. }\end{array}$ & $\begin{array}{l}\text { The year of primary school students was written in the } \\
\text { cover of the program handbook. }\end{array}$ \\
\hline 11 & $\begin{array}{l}\text { Active learning using smart board program } \\
\text { should be associated with the active } \\
\text { learning using smart board program } \\
\text { handbook. }\end{array}$ & $\begin{array}{l}\text { All lesson plan and worksheets of active learning using } \\
\text { smart board program were written in the active learning } \\
\text { using smart board program handbook. }\end{array}$ \\
\hline
\end{tabular}

Generally, all the experts strongly agreed with the features of the active learning using smart board program. They believed that the program could enhance and engage students' higher order thinking skills, reduce time in preparing teaching and learning materials, encourage active learning activities, as well as encourages student to participate in all classroom learning activities. Aside from promoting discussion and presentation among students, the program also encouraged students to put more effort to complete all the learning activities. In addition, students were prompted to have internal dialogue in which they verbalized understanding. Besides, all the experts also 
strongly agreed that smart board played an important role in the active learning using smart board program. Smart board allowed students to experience a range of new learning tool which encouraged engagement with course content and able to serve as an alternative to passively listening to lecture or simply reading texts. The touchscreen technology of smart board provides greater flexibility in the presentation of materials. It provides a large work space for hands-on activities with various multimedia resources, having a display surface huge enough to encourage high level of student interaction.

\section{$4 \quad$ Discussion of Findings}

Findings from questionnaire, interview $\mathrm{s}$ and excerpts from experts indicated that students and experts agreed that the use of active learning while learning Data Handling in class was effective. Active learning requires students' active participation, do meaningful learning activities and think about what they are doing. Active learning is prerequisite for effective and meaningful learning and help to achieve academic and other outcomes, such as critical thinking skills, openness to diversity, and growth in leadership and other job related skills [22], [26].

Nonetheless, the findings also indicated that the students and experts agreed that the use of smart board while learning Data Handling in class was effective. Studies that examined the use of technology in schools and its effectiveness found that use of technology is efficient for students [3]. The use of smart board in class has the potential to enhance students' knowledge and skills in Data Handling. As noted by [6], smart board has the advantage of adapting the manner in which the study material is conveyed to students' personal learning styles. It affords choices on various topics, develop knowledge, organize information, provide self-efficacy in carrying out assignments in a friendly environment, as well as support representation of products which generate a sense of success, pleasure, and contribute to a more creative and higher standard learning product [11]. Besides, students also claimed that smart board encouraged motivation to learn, raised the level of concentration, and had strong effect on behavior [25].

When smart board is incorporate with active learning environment, new pathways for students with varying learning styles can be developed. Compared to note-taking and traditional lectures, combination of active learning with smart board offers students with greater chances to directly participate with the content. A student and a teacher can interact with the smart board in front of the class, and the rest of the students remain involved. Having a display surface huge enough for everyone in the class to see encourages high level of student interaction. On the contrary, a lot of time is wasted on drawing of diagrams on blackboards, whereas by using a smart board, diagrams are drawn easily, and thus time is utilised more for active learning. In addition, students can read and manipulate information easily through the smart board. Instructor-mediated use of the smart board in academic libraries also clearly increases effective learning by increasing students' emotional involvement, engagement, social interaction, and self-esteem in library classes. 


\section{Conclusion}

To put in a nutshell, findings from the questionnaire, evidence from interview sessions with the students as well as excerpts from the experts showed that the active learning using smart board program could enhance primary school students' learning. Active learning provides opportunities for learners to think critically about learning content through a range of activities which help to prepare learners for the challenges in their daily lives. Active learning promotes higher order thinking skills which enables students to develop deep understanding of skills and content [14]. In addition, effectiveness of learning methods can be enhanced by using technology in class. Technology tool such as smart board is widely used in primary school nowadays. Most teachers in primary school agree that at present students prefer learning through smart board. Smart board allows students to experience a range of new learning tool which encourage engagement with course content, serve as an alternative to passively listening to a lecture or simply reading a text. Smart board using active learning program provide scaffolding for students to increase their higher order thinking skills levels. In addition, students can increase focus throughout the lesson, understand and learn better when smart board is used in class. In conclusion, active learning using smart board program is successful in providing active learning environment which can promote students to be active learners. Moreover, it provides an opportunity for students to share their learning using technological tools, develop advance thinking skills and cultivate lifelong learning. Therefore, active learning using smart board program should be widely introduced and used in schools to enhance learning among students.

\section{References}

[1] Adler, M. J. (1987). The Paideia proposal: An education manifesto. NY: Macmillan.

[2] Alakoc, Z. (2003). Technological Approaches to Modern Education in Mathematics Education. The Turkish Online Journal of Educational Technology, ISSN: 1303-6521 volume 2 Issue 1 Article 7. Atherton, J. S. (2010) Learning and Teaching; Constructivism in learning. Retrieved from http://www.learningandteaching.info/learning/constructivism.htm.

[3] Anderson, R. E., and Dexter, S. (2005). School technology leadership: An empirical investigation of prevalence and effect. Educational Administration Quarterly, 41(1), 49-82. https://doi.org/10.1177/0013161x04269517.

[4] Attride-Stirling, J. (2001). Thematic networks: an analytic tool for qualitative research. Qualitative Research, 1(3), 385-405. https://doi.org/10.1177/146879410100100307

[5] Beaty, L. (1997). Developing Your Teaching through Reflective Practice. Birmingham: SEDA.

[6] Becker, C., and Lee, M. (2009). The interactive whiteboard revolution: Teaching with IWBs. Victoria, Australia: ACER Press.

[7] Bligh, D. A. (2000). What's the use of lectures. San Francisco: Jossey-Bass.

[8] Chickering, A. W. and Gamson, Z. F. (1987). Seven principles for good practice in undergraduate education. AAHE Bulletin, 39(7), 3-7.

[9] Cross, P. (1987). Teaching for learning. AAHE Bulletin, 39(8), 3-7.

[10] Dale, E. (1969) Audiovisual methods in teaching, third edition. New York: The Dryden Press; Holt, Rinehart and Winston. 
[11] Dori, S., and Kurtz, G. (2015). Student's perceptions meaningful learning via ICT. Paper presented at the 2015 Chais Annual Meeting, Open University, Raanana.

[12] Franklin, C., Kader, G., Mewborn, D. S., Moreno, J., Peck, R., Perry, M., and Scheaffer, R. (2005). A curriculum framework for K-12 statistics education. GAISE report. American Statistical Association. Retrieved from http://www.amstat.org/education/gaise/.

[13] Gal, I. (2002). Adult's statistical literacy. Meanings, components, responsibilities. International Statistical Review, 70(1), 1-25. https://doi.org/10.1111/j.1751-5823.2002.tb00336.x

[14] Hill, A. (2013). Teaching in the new learning spaces retrieved from from https://www.jcu.edu.au/ data/assets/pdf file/0013/104332/jcu 125842.pdf.

[15] Hürsen, C., and Ceker, E. (2011). Evaluating Teacher Competencies In Using New Instructional Technologies. International Journal of Learning and Teaching, Vol 4, İssue 1, $1-13$.

[16] J. Scott Armstrong (2012). "Natural Learning in Higher Education". Encyclopedia of the Sciences of Learning.

[17] Jonassen, D. H. (2006). Modeling with technology. Mindtools for conceptual change. NJ: Prentice Hall.

[18] Kersaint, G. (2007). Toward technology integration in mathematics education: A technology integration course planning assignment. Contemporary Issues in Technology and Teacher Education, 7(4), 256-278.

[19] Keser, H., Uzunboylu, H., and Özdamli, F. (2011). The trends in technology supported collaborative learning studies in 21st century. World Journal on Educational Technology, Vol 3 , issue 2, 103-119.

[20] L. Dee Fardanesh, H. (2010). A Classification of Constructivist Instructional Design Models Based on Learning and Teaching Approaches. Online Submission, 16. Retrieved from http://www.ed.utah.edu/users/robert.zheng/6750reading/fardanesh.pdf.

[21] Martin, S., Diaz, G., Sancristobal, E., Gil R., Castro M. and Peire J. (2011). New technology trends in education: Seven years of forecast and convergence, Computers and Education, 1893-1906. https://doi.org/10.1016/j.compedu.2011.04.003

[22] Miller, R. L., Amsel, E., Marsteller Kowalewski, B., Beins, B. C., Kenneth, D. K., and Peden, B. F. (Eds.) (2011), Promoting student engagement, Volume 1: Programs, Techniques and Opportunities, Society for the Teaching of Psychology: American Psychological Association. Retrieved from http://teachpsych.org/ebooks/pse2011/vol1/index.php

[23] Moorhouse, E. (2007). Mt. Laurel district shows off digital classroom. Burlington County Times, Section B, p. 1-2.

[24] Özdamli, F., Cavus, N., and Uzunboylu, H. (2009). Evaluation of University Libraries. Cypriot Journal of Educational Sciences, 2(1), 9-20.

[25] Schuck, S., and Kearney, M. (2007). Exploring pedagogy with interactive whiteboards: A case study of six schools. Sydney: Sydney University of Technology.

[26] Smith, K. A., Sheppard, S. D., Johnson, D. W., and Johnson, R. T. (2005). Pedagogies of engagement: Classroom-based practices. Journal of Engineering Education, 94(1), 87-101. https://doi.org/10.1002/j.2168-9830.2005.tb00831.x

[27] Strauss, M., and Fulwiler, T. (1990). Writing to learn in large lecture classes. Journal of College Science Teaching, 19(3), 158-163.

[28] Vygotsky, L. S. (1978). Mind in society: The development of higher psychological processes (M. Cole, V John-Steiner, S. Scribner, and E. Souberman, Eds.). Cambridge, MA: Harvard University Press. https://doi.org/10.2307/j.ctvjf9vz4

[29] Webb, M. E. (2005). Affordances of ICT in science learning implications for an integrated pedagogy. International Journal of Science Education, 27(6), 705-735. https://doi.org/10.1080/09500690500038520 


\section{Authors}

Soh Hon Mun is a student at University Technology Malysia.

Abdul Halim Abdullah is a lecturer at the Faculty of Social Science and Humanities, University Technology Malysia.

Mahani Mokhtar, Dayana Farzeeha Ali, Nurul Farhana Jumaat, Zakiah Mohamad Ashari, and Norazrena Abu Samah are with the Faculty of Social Science and Humanities, Universiti Teknologi Malaysia, Johor Bahru, Malaysia

Mahani Mokhtar is a lecturer at University Technology Malysia.

Article submitted 2019-05-12. Resubmitted 2019-06-17. Final acceptance 2019-06-19. Final version published as submitted by the authors. 